\title{
Managed Retreat: A Rare and Paradoxical Success, but Yielding a Dismal Prognosis
}

\author{
Arjan Braamskamp, MSc \\ Dept. of Geography and the Environment, University of Oxford \\ South Parks Road, Oxford, OX1 3QY, UK \\ Tel: 018-6555-6756 E-mail: arjanb22@gmail.com \\ Edmund C. Penning-Rowsell, $\mathrm{PhD}$ (Corresponding author) \\ Flood Hazard Research Centre, Middlesex University \\ The Burroughs, London NW4 4BT, UK \\ Tel: 020-8411-5359Ｅ-mail: Edmund@penningrowsell.com
}

Received: February 6, 2018 Accepted: February 22, 2018 Published: March 20, 2018

doi:10.5296/emsd.v7i2.12851 URL: https://doi.org/10.5296/emsd.v7i2.12851

\begin{abstract}
Managed retreat (MR) involves permanent resettlement of existing households and communities away from areas at risk, here coastal flood risk. On post-Sandy Staten Island, New York, where MR has been successful, our research findings from interviews and a focus group of key stakeholders and commentators indicate there are very significant political impediments as well as financial constraints to MR programs being successful without the experience of a disaster and a repetitive sequence of hazardous events. Pre-disaster and long-term plans for reducing risks in such vulnerable areas are easy to advocate but not to implement. Many coastal locations globally will need some form of MR, where current risk is very high as a legacy of past decisions and where many communities will not be defendable against the expected future sea level rise. With leadership and community commitment locally MR agendas can and should be pursued: the optimistic scenario. But success appears likely only in the aftermath of a major disaster. This suggests strongly that we may have to await those inevitable disasters, and then be ready to act, rather than vice versa: a worrying conclusion and a dismal prognosis.
\end{abstract}

Keywords: Managed retreat, Hurricane Sandy, Staten Island, Flooding 


\section{Introduction}

Managed retreat as an adaptation to flood risk and climate change is much advocated but seldom achieved (Wong et al,2014; Hino et al.,2017). We approach this subject with the view that many coastal locations globally will need to consider this option, where current risk is very high as a legacy of past decisions and where many communities will not be defendable against the sea level rise expected by 2100 (Nicholls et al,2010; Hauer et al,2016). We also see implementation, however, as highly problematic.

Managed retreat (hereinafter MR) covers a multitude of actions, including community relocation, abandoning agricultural land, or simple habitat creation (Esteves, 2014). Here we restrict ourselves to a process that involves permanent resettlement of existing households and communities away from areas at risk (RPA, 2015). We also restrict our attention here to a voluntary process, not mandatory retreat or 'resettlement', because that would often be resisted, especially by those at risk, creating additional complexities (Hino et al.,2017; Bukvic et al,2015; Amnesty International,2008; World Bank, 2010; Nkwunonwo et al., 2016).

Most definitions of MR relevant here refer to vacating or re-purposing areas that were once developed and are now facing major disaster impacts (e.g. Alexander et al, 2012, 409). The land is permanently cleared and 'returned to nature'; alternatively, clearance may allow selective resilient rebuilding. Both may occur covering whole communities or gradually, property by property. The lexicon of terms includes managed retreat and buyouts (herein used), setbacks, managed realignment and permanent relocation. Generally, the policy is unpopular if communities are affected: most people do not welcome the need to move.

Without individual householder decisions to relocate, however, voluntary MR will not occur. De Vries and Fraser $(2012,15)$ suggest that a process of collective institution-based guidance is also necessary to negotiate outcomes, to prohibit redevelopment, and to provide the resources necessary for the property acquisition fundamental to a MR program that involves some form of government funding. Unless the affected communities can agree in sufficient numbers the policy can be inoperative or almost totally ineffective by leaving numerous isolated and vulnerable "holdouts" that are expensive to service. Inherent is a social multi-party process involving both the affected communities and the agencies of government, teasing out in that process a form of Rousseau's social contract between the government and the governed (Rousseau,1672) concerning the issues of risk and risk reduction.

Research into successful MR as an adaption to flood risk at the coast, voluntarily undertaken, is almost non-existent (see Hino et al., 2017). In this paper our objective is to address the conditions for MR success via property buyout programs in flood vulnerable areas, based on post-disaster interviews and a focus group. Our locus is the Borough of Staten Island, New York City (NYC), where three coastal neighbourhoods, located in the 1:100 year floodplain, comprise our research areas owing to the success of voluntary buyout programs there (Ocean Breeze; Graham Beach; Oakwood Beach (Figure 1). 


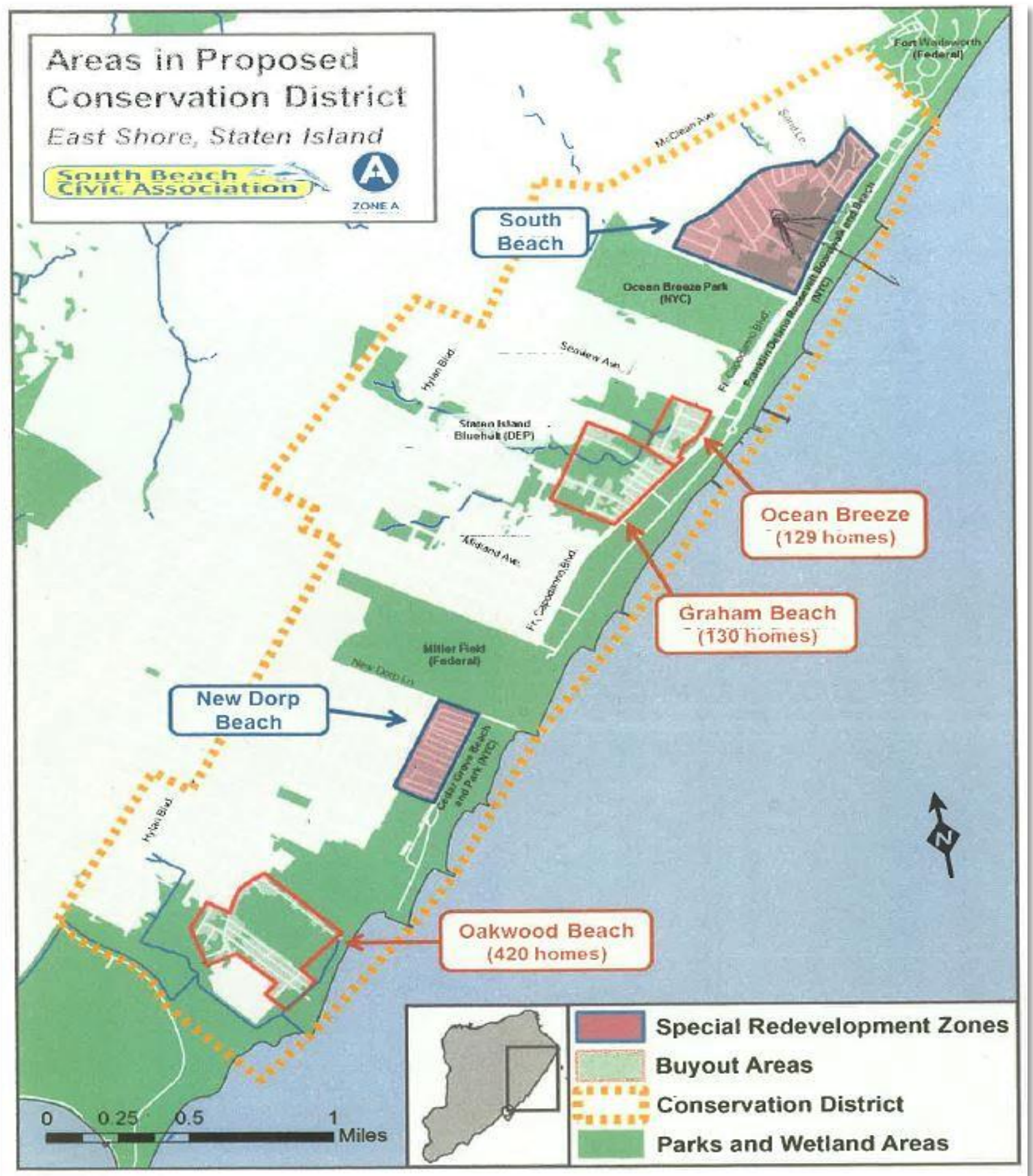

Figure 1. Enhanced buyout areas on Staten Island, New York City. Provided for use by the authors by Staten Island community representatives

$\mathrm{NB}$ one mile $=0.625 \mathrm{~km}$

Much of NYC was badly affected by 'Superstorm Sandy' but we chose to study Staten Island, first, because it suffered massive damage and 24 fatalities, more than any other NYC Borough $^{2}$, creating the incentive for a risk-reducing response. Secondly, this community is possibly as antipathetic to external intervention and as anti-government as anywhere in the

\footnotetext{
1 https://en.wikipedia.org/wiki/Effects_of_Hurricane_Sandy_in_New_York

${ }^{2}$ http://www.silive.com/news/index.ssf/2016/10/remembering_hurricane_sandys_v.html Accessed 21.12.15
} 
USA (Kramer and Flanagan, 2012). Notwithstanding this, paradoxically, MR has been successful here, on a large scale, facilitated and funded by New York State agencies, and we judged that research here may provide pointers for its prospects elsewhere. An important issue here is consensus, and whether it can be generated for MR when individual private homeowner interests are at stake (leading to a wish to stay) yet success depends on a significant majority of those affected agreeing to MR program implementation, without which the "holdout" problem becomes acute. We see consensus as more than just this agreement, but solidarity of belief or sentiment (Hartnett, 2011). This concerns both the decision and the process of reaching a decision on the need for action. Agreement on implementation and outcomes is also needed, so as to ensure effectiveness, and on the absence of realistic alternatives.

\section{Opposition, Advocacy and Limitations}

Permanently resettling existing households and communities away from areas at risk can incite opposition. The ability to withstand nature, by not retreating, fuels pride and social cohesion in the communities affected (De Vries and Fraser 2012). Some Staten Island residents evidenced their objection via painted slogans ("You can take our home, but you can't take our heart!" ). To them, "setbacks" and "retreat" were unacceptable defeat. The NYC post-Sandy Special Initiative for Rebuilding and Resiliency report endorsed this perspective (NYC SIRR, 2013), presenting adaptation options without mentioning retreat and citing New York's “toughness", defined as an unwillingness to retreat or surrender.

Managed retreat in its various forms is nevertheless widely advocated by many international organisations: the OECD (2010), Linham and Nicholls (2010), UNU-IHDP (2015) and the World Bank (2016). The idea has been explored in many countries (e.g. Breetzke et al, 2008; Hart, 2011; Mather and Stretch, 2012; Ryan et al, 2012; Barron et al, 2012; Roca and Villares, 2012). National governments have advocated its adoption: the UK is hoping for major coastal realignment in England and Wales by 2030 (Defra and EA, 2002; CCC, 2013; O'Riordan et al, 2014); MR in the USA aims at assisting coastal risk reduction requirements for unprotectable areas (NWF, 1998; NOAA, 2014; Kousky, 2014, Siders, 2013). The general objective is to reduce vulnerability to flooding and rising sea levels with global climate change (IPCC, 2001, 2014; EPA, 2009; Defra and EA, 2002), offering complementary ecosystem enhancement (McGranahan et al,2007; UNEP,2016; CCC,2013; DEFRA/EA,2002; Esteves,2014) and some favourable cost:benefit returns when compared to strategies based on defence (UNEP, 2016; CCC, 2013).

However, limitations are also recognised. The unpopularity of MR with the public and the consequential reluctance of government officials, elected or responsible to those elected (often faced also with the loss of local tax revenue from the cleared areas), can discourage implementation (Linham and Nicholls, 2010; IPCC, 2013, 2014; CIWEM, 2006). Another constraint is the generally high cost to taxpayers of MR should it be government funded: compensation for those relocated needs to be adequate to encourage cooperation yet full cooperation is very expensive (CIWEM, 2006; Daniel, 2001). Land, infrastructure and

\footnotetext{
${ }^{3}$ https://uk.pinterest.com/pin/268316090270852494/
} 
property values in intensively urbanized coastal zones (e.g. Manhattan and similar cities) may render retreat especially expensive and therefore unviable there (Linham and Nicholls, 2010, UNEP, 2016).

\section{Methodology}

Our research question was whether $M R$ can be a feasible adaptation strategy in flood-vulnerable high-risk areas, and under which conditions. Data collection at Staten Island occurred in June and July 2015, nearly three years after Sandy but when the MR process was still very active and memories of the disaster were still very fresh.

We used three complementary methods: literature analysis, semi-structured stakeholder interviews, and one focus group ${ }^{4}$. The research design was what is termed purposeful: we have not sought a representative sample of all actors, but have followed the guidance from Palinkas et al $(2015,533)$ that "(such) purposeful sampling is widely used ..... for the identification and selection of information-rich cases related to the phenomenon of interest". All our participants had a great deal of MR relevant information to share with us, thereby illuminating the key issues from both their organisations' and the residents' standpoints. We see consensus there as indicative of the likely consensus in their communities. We know that these are bold assumptions, but ones that we feel are justified by the match between their information and that from our analysis of the relevant grey and formal literature.

Our interview questions and focus group topics were developed after identifying four key but interrelated Sandy-relevant themes in the established hazards literature: the effect of Sandy on attitudes to risk, reactions and response (see White,1960; Kates,1962; Bukvic et al,2015); the viability of a longer term plan and strategy (see Albrechts,2004; Esteves,2014); development in hazard prone areas (see Tobin,1995; Parker,1995); and public engagement and incentives for MR (see Alexander,2012; De Vries and Fraser,2012). Discussing each theme with our participants involved them looking back at their experience of Sandy on Staten Island and forward to future MR programs both there and elsewhere.

Fourteen semi-structured interviews (Table 1) allowed participants to elaborate on topics of concern to them and, where relevant, to their institutions. We chose interviewees from what we see as key stakeholder and commentator categories across the decision-making spectrum: government; non-profit agencies; community leaders/members; academia. Individuals were selected following web and other searches based on two criteria: their personal Sandy experiences and their role in post-Sandy operations. Interviewees were approached by email, with a consent form and an overview of discussion topics. The 45 to 90 minute interviews were fully transcribed for review by individual interviewees, two of whom then provided additional information.

\footnotetext{
${ }^{4}$ All data gathering on Staten Island was undertaken by the $1^{\text {st }}$ author, who moderated the focus group.
} 
Table 1. Interviewees and their roles (interviews: June 17 to July 28 2015) with participants labelled I1 to I14 cited in the text

\begin{tabular}{|c|c|c|}
\hline Interviewee Category & Interviewees' roles & $\begin{array}{c}\text { Interview Code used in the } \\
\text { text }\end{array}$ \\
\hline Non-Profit & Urban Planner & I1 \\
\hline Community & Community Leader / Member & 12 \\
\hline Non-Profit & Emergency Response Manager & 13 \\
\hline Government & NYS Officials (4x) & 14 \\
\hline Government & NYC Official & 15 \\
\hline Academic & Graduate Researcher & 16 \\
\hline Government & NYC Official & 17 \\
\hline Government & NYC Official & 18 \\
\hline Community & Community Leader / Member & 19 \\
\hline Academic & Professor & 110 \\
\hline Academic & Associate Professor & I11 \\
\hline Non-Profit & Environmental Advocate & 112 \\
\hline Community & Community Leader / Members (4x) & I13 \\
\hline Government & $\begin{array}{l}\text { NJ State } \\
\text { Official }\end{array}$ & I14 \\
\hline
\end{tabular}

Through the two-hour focus group we explored ideas and opinions in a more discursive manner, focused around eight pre-determined statements concerning the four themes as particularised for Staten Island through our interviews (Table 2). The process yielded qualitative and quantitative data, the former recorded throughout the discussions and used via our systematic transcript review to identify common and stakeholder relevant themes complementing our other information (Carey and Asbury, 2012). Selection for the group required voluntary participation and existing knowledge of or experience with MR on Staten Island and NYS/NYC interactions.

We did not seek a homogenous group, which we recognise as general focus group practice (Morgan, 1997). Instead we used an equal representation of buyout community leaders for their local insights and academic resilience specialists to tap into wider issues, so as to explore the interrelations and differences between the two inputs. The community leaders constituted two from Ocean Breeze and one from Oakwood Beach. While the MR process 
was active our focus was on these community leaders, who indicated reaching out to individual householders would be an extremely difficult undertaking. Those that had successfully negotiated agreements with NYS for a buy-out had moved out of the area and those still in the buyout process were bound by non-disclosure regulations as stipulated by the terms of the buyout agreement. Finally, the holdouts, largely frustrated and emotionally exhausted in the Sandy aftermath, were either unwilling, unavailable or unidentifiable during the data collection phase. The academics involved two College of Staten Island professors, one Science/Physics, one Finance and Economics, plus one researcher of social aspects post Sandy. To complement the qualitative data a confidentially deployed Likert scale (Trochim, 2006) captured individual attitude patterns quantitatively, for comparison with the interview findings.

Table 2. Focus Group Quantitative Findings with participants labelled FG1 to FG6 cited in the text

\begin{tabular}{|c|c|c|c|c|c|c|c|c|}
\hline Topic & Substance & FG1 & $F G 2$ & FG3 & FG4 & FG5 & FG6 & $\begin{array}{l}\text { Summary/ } \\
\text { consensus }\end{array}$ \\
\hline 1 & $\begin{array}{l}\text { Incremental development of housing } \\
\text { and infrastructure in flood-vulnerable } \\
\text { areas is inevitable in densely populated } \\
\text { urban areas. }\end{array}$ & SDA & DA & DA & SA & A & A & $\begin{array}{l}\text { Split between } \\
\text { academics and } \\
\text { the others }\end{array}$ \\
\hline 2 & $\begin{array}{l}\text { Lack of communication or public } \\
\text { engagement between Staten Island } \\
\text { authorities and residents hinders the } \\
\text { effectiveness of adaptation programs. }\end{array}$ & SDA & SA & SA & NO & A & SA & $\begin{array}{l}\text { Most agree, one } \\
\text { dissent }\end{array}$ \\
\hline 3 & $\begin{array}{l}\text { Without a natural disaster, there is } \\
\text { insufficient momentum or urgency to } \\
\text { implement long-term adaptation } \\
\text { strategies in Staten Island. }\end{array}$ & SA & NO & SA & A & SA & SA & $\begin{array}{l}\text { All agree, most } \\
\text { strongly }\end{array}$ \\
\hline 4 & $\begin{array}{l}\text { Staten Island would benefit from a } \\
\text { permanent retreat / buyout program } \\
\text { available to residents in vulnerable } \\
\text { locations. }\end{array}$ & SA & A & A & SA & A & SA & $\begin{array}{l}\text { All agree, } 50 \% \\
\text { strongly }\end{array}$ \\
\hline 5 & $\begin{array}{l}\text { The financial incentives offered } \\
\text { through the New York State buyout } \\
\text { program are sufficient for the program } \\
\text { to be effective. }\end{array}$ & SA & NO & SDA & A & SA & A & $\begin{array}{l}\text { Most agree, one } \\
\text { dissent }\end{array}$ \\
\hline 6 & $\begin{array}{l}\text { The US Army Corps of Engineers' } \\
\text { seawall offers a more cost-efficient } \\
\text { adaptation option than the buyout } \\
\text { program. }\end{array}$ & SDA & SDA & SA & NO & NO & NO & $\begin{array}{l}\text { Split views with } \\
2 \text { strongly } \\
\text { disagree }\end{array}$ \\
\hline 7 & $\begin{array}{l}\text { Managed retreat or buyout programs } \\
\text { require } 100 \% \text { participation to be truly } \\
\text { effective. }\end{array}$ & SA & NO & SA & SDA & DA & DA & $\begin{array}{l}\text { Split between } \\
\text { academics and } \\
\text { the others }\end{array}$ \\
\hline 8 & $\begin{array}{l}\text { Staten Island was / is not prepared to } \\
\text { deal with the consequences of Sandy in } \\
\text { terms of long-term recovery. }\end{array}$ & SA & NO & SA & A & A & SA & Most agree \\
\hline & & \multicolumn{3}{|c|}{ Academics } & \multicolumn{3}{|c|}{$\begin{array}{c}\text { Community } \\
\text { members }\end{array}$} & \\
\hline \multicolumn{9}{|c|}{ Likert scale applied: Strongly Disagree (SDA); Disagree (DA); No Opinion (NO); Agree (A); Strongly Agree (SA) } \\
\hline
\end{tabular}


While anxiety generating events such as buyout programs are in full swing, research such as reported here can be problematic. For example, some of the relevant terminology ("setback"; "retreat"; etc) may precipitate antagonism, and some invitation non-response was inevitable (although $<3$ individuals). However our relatively small sample sizes, though not unusual in qualitative research, appear sufficient to capture most attitudes and relevant information. Our confidence here results from the many matches seen in our data with the results of our analysis of the very extensive documentary and media information from the aftermath of Sandy and since. The research sought to be as objective as possible, helped by the three complementary data sources. But the findings are the - subjective - opinions and feelings of our participants and these dominate the character of this paper.

\section{The Geographical, Social and Policy Context}

\subsection{Staten Island Flooding and its Socio-political Context}

Hurricane Sandy (29.10.2012) had a significant impact on the New York (NY) region, especially on Staten Island (Knafo and Shapiro, 2012; NPCC, 2010; Benimoff et al, 2015; Gornitz et al, 2001). Some $16 \%$ of the Borough was flooded, impacting approximately 76,000 residents 5 . Ocean Breeze, Graham Beach and Oakwood Beach all suffered badly. Damage in the State amounted to $\$ 32 \mathrm{bn}^{6}$ with Staten Island accounting for 23 percent of NYC damaged properties ${ }^{7}$.

While events of this magnitude are rare, hurricanes in 1932 and 1938 had produced 4.0-6.0m storm surge heights but the associated flooding went largely unnoticed: the majority of Staten Island's coastal areas then were undeveloped marshlands (Benimoff et al, 2015) ${ }^{8}$. These areas, largely at mean sea level, buffered incoming surges. Since then continuous urbanisation has placed large numbers of houses at risk (Benimoff, 2010).

Socio-politically, most Staten Islanders have strenuously sought independence from external influence (see Kramer and Flanagan, 2012). They have generally voted Republican (40\% for Clinton and 57\% for Trump in 2016, with Trump at 75\% on flood-vulnerable South Shore ${ }^{9}$ ). Predominantly white working or lower middle-class owner occupiers with many years of residency (Binder et al (2015) they have sought and still seek to minimise government interference. Until Sandy, a manifestation of such independence, according to Kramer and Flanagan (2012), was the lack of coherent spatial planning and building code compliance here, and the generally unchecked development in the low-lying coastal areas.

Not until 1964 was Staten Island connected to Brooklyn via the Verrazano-Narrows Bridge (Barron, 2014), leading to substantial settlement on the Eastern and Southern beaches which until then were predominantly inexpensive summer communities with single-storey

\footnotetext{
5 http://www.nydailynews.com/new-york/hurricane-sandy/hurricane-sandy-year-staten-island-article-1.1494052

${ }^{6}$ Library, C. N. N. "Hurricane Sandy Fast Facts - CNN.com". CNN. Retrieved 2016-10-27.

7 http://www.nyc.gov/html/sirr/downloads/pdf/final_report/Ch15_Staten_Island_FINAL_singles.pdf

${ }^{8}$ http://www.historicmapworks.com/Map/US/39402/Historical+Geology+Sheet+003+++New+Jersey+++New+

York+Staten+Island+Quadrangle/New+York+City+1902+Geological+Atlas+of+the+United+States+Vol+83/Ne w+York/

9 http://www.silive.com/news/index.ssf/2016/11/heres_how_donald_trump_fared_o.html
} 
properties (Benimoff, 2010). Many such temporary homes that were upgraded and winterised as all-year dwellings were wrecked by Sandy.

\subsection{The Buyout and Acquisition Programs (NYS)}

In targeting potential buyout areas generally, U.S. government agencies identify highest-risk properties based on repetitive losses (Siders, 2013; NWF, 1998). This reduces insurance claims, particularly relevant where insurance programs are public, such as the Federal Emergency Management Agency's (FEMA's) U.S. National Flood Insurance Program (NFIP). Technically, FEMA can require buyouts of properties damaged and losing more than $50 \%$ of their pre-flood values ${ }^{10}$, but they do not typically do this, for many reasons, with the unacceptability of mandated retreat "from above", being an important one.

Managed retreat after Sandy was implemented by a series of buyout initiatives. In terms of policy and related government intervention, several property acquisition programs were available in the region, with eligibility depending on significant Sandy-related damages and property location. In January 2013, U.S. Congress made disaster recovery funding available to various regional authorities, including authorisation for property acquisitions or buyouts (NYS GOSR(1), 2014) for "properties located in the floodplain (and) intended to reduce risk from future flooding” (U.S. Congress, 2013, 14345). New York State (NYS) promoted MR as an adaptation strategy. Both buyout and acquisition programs were offered (NYS GOSR(1), 2014). The acquisitions program used post-storm property values, with additional housing assistance, whereas the buyout program used pre-storm values and additional incentives depending on individual circumstances.

The buyout program - our research focus - had a distinct environmental and resiliency component, prohibiting future development in perpetuity: the vacated land can only be used for open space, recreation or wetland restoration (NYS GOSR (1), 2014). The acquisitions program allows for new or upgrading property, and is perceived by many as a redevelopment scheme. The policies were flexible, reflecting local differences. Targeted buyout was an attempt by NYS to purchase groups of adjacent properties, in a predetermined location, to restore natural conditions (NYS GOSR (1), 2014) and minimise the problems inherent in "holdouts".

Eleven applications were received from communities for the NYS Buyout program, but only three were accepted for enhanced buyout status: Oakwood Beach, Ocean Breeze and Graham Beach (I4 ${ }^{11}$ ) (Figure 1) (NYS GOSR (2) 23014). NY State Governor Cuomo allowed homeowners in the enhanced buyout zones to claim a $10 \%$ premium over pre-storm values. Eligibility involved properties being situated in FEMA designated 1:100yr flood zones (State of New York, 2015).

With strong community support, and a strong champion recommending buyout ${ }^{12}$, this became a large program. Oakwood Beach was first in line; 99\% of homeowners there

\footnotetext{
${ }^{10}$ http://www.clm.com/publication.cfm?ID=424\#_edn2

11 i.e. interviewee No. 4; interviewee numbers are given in Table 1.

${ }^{12}$ http://www.crainsnewyork.com/article/20141020/REAL_ESTATE/310199992/oakwood-beach-sell-out-tear-do wn-and-leave Accessed 28.12.16.
} 
submitted buyout applications by 2016. The government spent $\$ 301$ million here, acquiring 296 out of a targeted 326 properties (Freudenberg et al, 2016). By 2016, 60 homes had been demolished (Freudenberg et al 2016). In 2014, buyout programs were also approved at Graham Beach and Ocean Breeze, promoted by local champions and the support of the Oakwood Beach protagonist, each with 130 homes planned for purchase (New York Government, 2014). In the program overall, 679 homes were eligible for enhanced buyout (I4) and 350 homeowners had quickly settled by June 2015. The final total of properties purchased remains confidential but large areas were guaranteed to be 'returned to nature' (NYS GOSR(1), 2014).

\subsection{The Adjacent Build-it-Back (NYC) and the Blue Acres Buyout (NJ) Programs}

Our research focused on the NYS buyout program, but alternatives nearby almost certainly affected attitudes to any potential buyout program by showing what MR arrangements were possible. New York City, while acknowledging its increased vulnerability, insisted retreat was not an option. Their Build-It-Back program enabled low income households to sell their homes to the City. Properties would be rebuilt or reinforced against coastal flooding (Baussan and Peterson, 2015), with mandatory new elevation levels and resilient materials (NYC, 2015a). The program appears to have been slow in its implementation procedures and heavily criticised publically (NYC, 2015b).

In adjacent New Jersey (NJ) the Green Acres Program can acquire privately-held land for environmental gain. The Blue Acres project, as part of Green Acres, provides an acquisition option for properties "damaged by ... storms or storm-related flooding” (NJ DEP (1), 2015, 1). But voluntary buyouts after extensive flooding here from Hurricanes Floyd (1999) and Irene (2011) had been limited by budgetary constraints: demand here far exceeded the funding and political support from municipalities and the State government. After Sandy, however, this also became a large program (NJ (DEP) (2) 2015; NJ (DEP) (3) 2015), acquiring more than 500 homes $^{13}$.

At least two potential successes therefore rapidly emerged after Sandy: Oakwood Beach and nearby Blue Acres (above, in NYS and NJ). A paradox arises here regarding the Staten Islanders' reliance on funding and state support and their strongly independent identity and aspirations. The success of such public interventions would appear to require strong levels of public engagement, consensus and good relationships between residents and government in its various forms (Siders, 2013). On Staten Island, that level of multi-party engagement or Rousseau-type social contract was not only largely absent before Sandy, but very far beyond the 'comfort zone' of the average homeowner (again, see Kramer and Flanagan (2012)). This was an important context for our research.

\section{Our Findings: Managed Retreat Explored As a Social Process}

We present the key issues related to voluntarily agreed community level MR here in terms of the four themes outlines above using the findings from our focus group and interviews.

\footnotetext{
${ }^{13}$ http://barnegatlighttaxpayer.org/since-sandy-500-nj-properties-acquired-through-blue-acres-buyout-program/ Accessed 28.12.16
} 


\subsection{Theme 1: Risk and Reactions}

Comprehensive MR - without leaving too many "hold-outs" as residual isolated vulnerabilities - required consensual thinking. Starting at Oakwood Beach but spreading to our two other areas (and elsewhere), local communities came together to seek state funded property buyouts, with little initial local (NYC) support. A key issue revealed here is that MR as on Staten Island - unfortunately - is only feasible (and would only be likely elsewhere) if implemented in the wake of a disaster and the risks thereby revealed.

Our focus group's Topic 3 (Table 2) explored support for this 'window of opportunity' concept. We found strong insistence, without dissent, that a major disaster was necessary to trigger the required momentum and sense of urgency for the implementation of adaptation strategies on Staten Island (implicitly including buyout). The community representatives were sceptical of the timing of buyout programs and its effect on success, but "If you can get the answers quicker (after a disaster), people make better decisions" (FG3). If authorities wait too long with their offers and their conditions, the initial shock wears off, the water recedes and people are reminded of all the good reasons why they were living in this unfortunately high-flood prone area. If the initiatives take too long to mobilize, people change their minds and want to stay, making the potential success of the buyout program more unlikely, due to a larger number of holdouts.

Our interviewees agreed. A general view here was that it is difficult, if not impossible, to generate the necessary social, political and economic momentum for MR programs as a norm without an actual disaster. None endorsed the notion that the general focus on adaptation in the New York region at that time - and related funding - would have been possible without Sandy. The academic and government interviewees were more specific. They acknowledged the inability of the current political process to generate sufficient support for high impact programs like MR in absence of a trigger event (I4; I5; I7; I10). The momentum to act is short-lived and society collectively forgets and moves on (I7). Despite the existence of a buyout program, if the period between the storm and the conclusion of buyouts is too long, community members gradually start to change their minds (I13).

The community interviewees offered a complementary local perspective. Sandy was not the single reason for the success of the MR program: repetitive flooding and brushfires over many years had pushed many residents into considering their options (I13). But there was a balance to be struck: the buyout communities were seen by many as highly desirable places in which to live. Proximity to the beach and the tranquility of living in the wetlands within the NYC area at a reasonable cost and - initially - with low insurance premiums far outweighed the drawbacks of repetitive flooding, prior to Sandy (I2; I11; I13). However, after just finishing repairs from Hurricanes Lee and Irene, Sandy was the "last straw": there is a certain amount of personal drama that people can endure, before they reach a point of drastic decisions, like giving up their homes (I2, I9, I4).

Without a major trigger event a large majority in the focus group did not have confidence that adaptation considerations, particularly socially disruptive buyout programs, would surface on to political agendas or even into the public consciousness (Table 2, topic 3). Regarding MR, 
participants were more specific, firmly supporting the triggering process. "It does not matter how smart or how right you are, when it comes to where people live and property values (after a disaster), everything else goes out the window" (FG5). "Nobody would listen to you (before Sandy)" (FG4) and "crisis du jour" was the driver for a consensus and for change (FG6).

Exploring whether the post-disaster situation triggered more radical policies, the use of eminent domain (compulsory purchase) was universally dismissed by our interviewees as an undesirable or impractical retreat strategy: all available buyout and acquisitions-for-redevelopment programs in place in the NY region are on a voluntary basis (I4; I5; I7; I12). Additionally, eminent domain would conflict with the use of Federal emergency funding and thus is not an option in a post-disaster scenario (I2, I14). Antagonism to vacating private properties without an imminent threat would apply to both government and residents alike (I2, I4, I5, I7, I10). "People want to be left alone and you are not going to get them to pick up and go, unless there is a danger that forces them to change their lifestyle" (I10).

There are always options, and to tackle the legacy from past poor decisions one alternative to waiting for a disaster is a permanently available buyout program (Table 2, Topic 4). Unanimous focus group member support here may appear contradictory, given their insistence on a disaster as a trigger, but the academics and residents alike supported residents having options, should they decide to be bought out and leave, even though aware of the governmental budgetary constraints that limit buyouts.

Our interviewees were more divided. NYC officials emphasized housing stock needs (hindered by retreat and the consequential property demolition) and the value of their Acquisitions for Redevelopment "Build it Back" program (I5,I7). NYS officials were worried about on-going large funding requirements, when considering scaling up MR programs (I4). Without an immediate need with a major disaster, our NYC and NJ officials affirmed that no Federal Emergency Funds would be available, which makes permanent retreat programs less viable (I5, I7, I14). Available funding rises ten-fold in post-disaster scenarios and the US $\$ 300 \mathrm{~m}$ Federal dollars committed towards New Jersey state-wide buyouts (I14) would not have been available, without Sandy, for proactive initiatives. Planning for resilience measures, long-term, comes with the virtual certainty of significantly less finance, especially for buyouts (I7).

The timeline difference between disaster recovery plans and political office terms was also seen (I5) to remove the urgency for politicians proactively to introduce such impactful topics as MR within resiliency planning: the majority of MR's resilience benefits will occur far beyond political office timescales, yet all the public expense and effort is needed "up front" in the short term.

We see these findings as amply illustrating the well-known risk-response phenomenon: disasters are the principal drivers of the economic, financial, social and political consensus and momentum necessary to trigger policy or attitudinal change, whether such change is incremental over many years (Albrechts, 2004) or catalyst-driven by single events (Johnson 
et al., 2005). In the case of buyouts, these are unpopular amongst those householders affected, and only a major event provides the window of opportunity, the resources and the individual's motivation for them to surface as real options.

\subsection{The Theme 2: Long-term Planning, Strategy and Benefits}

The feasibility of MR may improve if alternatives are seen as less viable by those affected and, additionally, if MR is part of a comprehensive long-term plan relevant to both disaster and non-disaster situations. Our focus group's Topic 6 (Table 2) was used to gauge opinion about one alternative in the form of the publically announced seawall plan for protecting part of the Island from flooding ${ }^{14}$, and to appreciate how people evaluate different options: here engineering-dominated solutions versus retreat strategies (with any necessary engineering component). Discussing interactions between the two, the possibility of buyout participation rates being negatively affected by the seawall announcement was dismissed by the group's community members as irrelevant due to the major uncertainty regarding its actual implementation.

This seawall discussion nevertheless highlighted various perspectives. Firstly, the cost-benefit analysis was seen by the academics in the group to produce a favourable verdict here, when compared to MR. Costing US\$580m (estimated), the seawall could protect approximately 11,000 households. With 350 buyouts costing US $\$ 140 \mathrm{~m}$ (the numbers then available), buyout is significantly more expensive per dwelling. There is a steep premium to be paid for complete risk reduction - the buyout program - versus the "acceptable risk reduction" option the seawall. Of course, this comparison promoted discussion on what constitutes acceptable in terms of human casualties related to the residual risk with the seawall and its finite cost: benefit driven design standard; the seawall was seen here to have limitations, and might in any case never be funded.

Secondly, the seawall was projected to produce a false sense of security, reduce flood insurance rates behind the wall and make living in the area more attractive: development therefore would accelerate, placing more homes in the floodplain (I6). Without strong policies that control development, as virtually nonexistent on Staten Island in the past, such protection schemes could have a detrimental long-term effect on a region's resilience, reducing the perceived threat of extreme weather events and hampering any necessary disaster driven evacuation efforts (I6).

Thirdly, all of our community members, as interviewees and in the focus group, were skeptical regarding the likelihood of the seawall ever being built. Seawall discussions have been ongoing on Staten Island for more than 30 years and despite numerous government indications about feasibility and necessity, the wall has never materialised. Those attitudes appeared to be illustrative of some strained or non-existent relationships between Staten Islanders and the government, in this case the U.S. Corps of Engineers.

There are other coastal risk reduction alternatives, and focus group Topic 8 (Table 2)

\footnotetext{
${ }^{14}$ http://www.ny1.com/nyc/all-boroughs/news/2015/08/20/army-corps-of-engineers-shares-plans-for-seawall-onstaten-island-s-east-shore.html Accessed 29.12.16
} 
reviewed longer term prospects. This produced not only very strong statements of non-confidence in Staten Island's current short-term and long-term planning capabilities but also invoked a wave of emotion and criticism directed at government in general. That NYC's Office of Emergency Management (OEM) was bypassed completely after Sandy incited the focus group participants, particularly in the absence of other arrangements. Illustrative of the level of public frustration, the controversy surrounding the 2012 NYC marathon, scheduled for five days after Sandy but cancelled at the eleventh hour, touched at the heart of the issue. While Staten Islanders were reeling from the storm, NYC decreed that the mobile 'Port-a-Johns' toilets for the runners were not for use by Sandy victims, identifying for members of our group a serious disconnect between government authorities and residents. The inability to deploy some form of 'disaster and recovery playbook' ${ }^{15}$, providing guidelines, structures and best practices to enhance recovery in disaster-impacted communities, was heavily criticised by all our participants. Planning and plans were uniformly distrusted.

But a seawall versus a MR plan or other alternatives was seen as too simplistic; MR would always need to be part of a larger adaptation strategy (I1,I4,I5,I7,I12). This is partially due to budgetary constraints surrounding retreat, given its expense, but also practicality and the feasibility of implementation. That only three of the eleven communities applying for the NYS Buyout Program were selected was cited as an example (I4). The other eight communities were assessed on the same range of criteria, including elevation above sea level and inundation during Sandy (I4), but instead they were designated for redevelopment or property elevation programs. Managed retreat was too expensive and too difficult to be applied everywhere: NYS simply did not have sufficient resources.

The NYS officials interviewed (I4) suggested that their response to Sandy has been reactive but also forward looking. The engagement of communities was the result of the storm, but it was aimed at being better prepared for the future: "It is about building back better (elsewhere)" (I4). Furthermore, the officials emphasised that their restricted deed on buyout property lots was a key factor for many homeowners. The fact that an individual sacrifice would benefit future generations by vacating land, recreating wetlands, and thereby increasing overall resilience of Staten Island was an important driver behind the success of the NYS buyout program (I4).

The general consensus with our interviewees is that buyout cannot operate effectively without post-disaster funding and momentum and that long term programs are often supported, but are problematic to implement. But value was nevertheless seen in maintaining long-term buyout programs: their strength lies in the framework and capacity put in place during non-disaster times (I1,I5,I11,I12,I14); they support officials who later want to act on post-disaster momentum by implementing resilience strategies, including the buyout option (I1,I14). They promote awareness of MR and an opportunity for homeowners to seek buyout at a less stressful time.

Blue Acres was cited as a potential template in the NY region, and possibly nationwide

15 http://disasterrecoveryplaybook.org/home.html 
(I5,I11,I12). Not heavily promoted before Sandy, the program then provided a pre-existing conduit for incoming funds and operated more efficiently than would any new initiative (I12,I14). Asked if the efficiency of spending Federal funds for MR programs increased with an existing vehicle in place, the NJ official replied: "Oh yes, 100\%. 100\%!" (I14). A disaster catalyzes an existing process.

Buyout programs were therefore seen to require a complementary overall strategy. The need for long-term resilience planning for Staten Island and the New York region was clear from all the interviews and at the focus group. How to achieve it was far less clear. "Shame on New York City, because we did not have a better plan! We have OEM (Office of Emergency Management) and several thousands of people on staff, but we did not have anybody to deal with this (Sandy) scenario" (I13).

We see these Staten Island findings as an indication that successful MR as an adaptation tool is likely to depend on the mix and viability of other feasible strategies available. More often than not, other adaptation tools may be more suitable and feasible. Buying out an entire neighbourhood might be viable for smaller, less populated communities, where all risk can be mitigated with a single buyout plan (as I7 suggested). The reality of NYC - and its density of houses and people - may suggest more efficient ways to invest in risk mitigation, keeping urban communities in the floodplain, beginning a dialogue with communities about their risk and finding ways to strengthen their resilience in future through protective or accommodating measures (favoured by I5,I7). Such long term resilience planning will require difficult decisions, meaning that in some neighbourhoods an effective and permanent buyout program will be the best way forward (I12). In other places a better decision may be to build flood defences (I12). Nothing is clear-cut, nor is success guaranteed, especially where antipathy is common - as on Staten Island - towards planning per se.

\subsection{Theme 3: Development in Floodplains}

We explored here whether the feasibility of MR improves if policies are in place restricting subsequent development in flood-vulnerable areas and the people whose homes will be demolished can judge that the legacy of unwise decisions in the past is being addressed.

Here we saw significant participant disagreement. Our interviewees suggested that economic opportunity tends to conflict with responsible development. NYC has a responsibility to determine and direct growth within the city (I5). In that sense, long-term planning and related zoning are important. However, as a tool to control development, zoning can be limited in its effectiveness: if zoning strictures are not endorsed by developers and supported by the market, envisioned planning objectives will go by the wayside (I5). What further complicates matters is that development is such a slow-moving process. Urbanization levels on Staten Island had doubled between 1960 and 1980, but before that development happened one dwelling at a time, so encroachment of risky areas within the 100-year floodplain was largely hidden.

Many U.S. regulations regarding wetlands protection and responsible building standards in floodplains also date only from the 1980s and many of the most vulnerable houses in the floodplain on the Island's Eastern shore predate those regulations; they were "grandfathered 
in" and never required to comply with the new regime (I13). Our interviewees indicated that many residents stated they were misinformed about flood insurance requirements and the flood zone was very rarely a consideration in purchasing houses in the area, despite publicly available information showing a 1:100 year floodplain. The relevant properties were never meant to be lived in year-round, and were hit hard during Sandy (I4,I7). In reality, planning was non-existent on Staten Island for many years and the residents (not unhappy with this) were at the mercy of local officials seeking locations for development and developers seeking strong ties with local government officials (I13). A booming population and a perpetual housing shortage in NYC provides a likely explanation why some of the Staten Island communities have been built in such vulnerable locations, based often on poor or partial risk information.

Compromises now were favoured by some interviewees. The pressure now to accommodate a growing NYC population makes large-scale buyout programs undesirable as well as financially impossible. That fuels redevelopment programs at the expense of MR programs. The ultimate NYC objective is to maintain levels of available and affordable housing, while using the momentum from Sandy to upgrade to a more resilient housing stock (I5), even if that means maintaining residences and infrastructure in risky, flood-vulnerable areas.

Our focus group Topic 1 (Table 2) sought to provoke discussion on the level of control that governments can and should exercise over development processes. However, the discussion was somewhat unfocused, due to different interpretations of the inevitability of incremental development in flood-prone areas. Some participants interpreted it using the current situation and looking forward, whereas others approached the theme historically (perhaps not wanting to discuss the future). Both discussions did however reflect a frustration with a development process that apparently cannot be controlled here, neither by educating people nor even in the wake of a major storm event.

The academic in strong disagreement with the apparent inevitability of lack of control over development emphasised that proper education about flood zones and evacuation routes will make a difference and enhance resilience. However, the community members disagreed: education alone will not suffice. "You can educate them all you want, but when it comes to money, it is not going to make a difference"(FG5). There was some agreement that the government has a role to play in mandating the private sector to incorporate flood damage disclosure on real estate transactions and in restricting building approvals in high-risk areas. However, no focus group participant was convinced that governments can successfully overcome their political ties to the real estate and building community on Staten Island.

Similar sentiments, regarding the role of government and the lack of regulatory enforcement, were worded even more strongly in some of our interviews. All of the community leaders indicated that some of the development in their respective communities should probably never have happened (I2,I9,I10,I13). However, the fault was not with the homeowners, but with local elected officials who approved the development (I13) and failed to enforce building standards and environmental requirements of building in or near the wetlands (I2). Without collectively agreed standards individuals are at risk of making unwise decisions. 
It was again stressed that the development of the most vulnerable communities was a slow, incremental process. Beach communities were upgraded long before building and flood zone standards were enforced (I2,I4,I5,I7,I9,I13). However, that did not mean that these communities should never have been built, but there should have been stricter governmental enforcement once people started using their homes year-round (I13). Even with retreat programs, thanks to sea level rise we will always be close to the water and flood risk will not disappear. The focus should be on how that risk can be reduced to what they saw as acceptable levels, difficult though these were to define (I7).

The consensus was that what they saw as Staten Island overdevelopment has occurred due to lack of oversight (I2). Not only have local officials failed to control development in low-lying floodplains, they have actively encouraged it in exchange for political support (I2,I9). Various NYC officials and agencies pursued conflicting interests. As environmental agencies were using wetlands as part of Staten Island's BlueBelt stormwater reduction program ${ }^{16}$, local Staten Island officials were issuing building permits in those same, now vulnerable, areas (I2). With better coordination amongst agencies and the right planning policies, urbanisation on Staten Island's Eastern shore could have been restricted. The perceived continuing absence of inter-agency coordination was seen as further fueling the communities' distrust of government interventions.

Looking forward, there was less agreement, mainly about feasibility. To persuade communities to participate in buyouts, for some general good, policies need to be introduced and enforced to prevent the historic overdevelopment from happening in the future (I12)(see also Koslov,2016). All tools at our disposal to promote and incentivise responsible development in the future were seen to be needed. This included stricter zoning regulations, compliance with resilience and flood standards for new construction, removal of legal barriers to facilitate resilience compliance and greater capacity within oversight authorities. Only in the context of that level of commitment to area development, could MR be successfully introduced as a resilience measure to tackle legacy areas where vulnerability is demonstrably high.

We judge, however, that this way forward may be a huge challenge, considering rebuilding had already started in locations that were wiped out during Sandy (reported by community interviewees I2, I9, I13). At the time of our research construction was ongoing in sections of Ocean Breeze, which was hit particularly hard: As one community focus group participant remarked "Another storm is needed to stop the development in this high-risk, flood-vulnerable zone" (FG5).

\subsection{Theme 4: Public Engagement, Transparency and Incentives}

Managed retreat may become more feasible if residents can be properly incentivised, including through full transparency and public engagement before, during and after a disaster. However, there are research process issues here. Because of the emotional personal experiences and prolonged trauma that residents were still experiencing in Sandy-damaged

${ }^{16} \mathrm{http}: / /$ www.nyc.gov/html/dep/html/dep_projects/bluebelt.shtml accessed 21.12.16. 
communities at the time of our data gathering, it unsurprisingly proved difficult to get an unemotional view from community members interviewed on several issues involving long-term recovery. Their focus tended still to be on the short-term emergency (I9, I13). Local community-based aid organisations, advocacy groups and academics were able to provide more detached but perhaps less 'real world' opinions (I3; I11), both about the community response and the level of government engagement. Residents and government officials were quite possibly too close to either end of the governed/government spectrum to be able to offer a truly objective response (whatever that might be in the circumstances).

Notwithstanding this, there was strong majority view in our focus group - topic 2 (Table 2) that relationship-building between governments and communities needs to happen in non-disaster (i.e. pre-disaster) situations, as part of disaster prepreparedness. Two issues were critical here: the lack of government capacity and knowledge to act after Sandy and the resulting communication failures. Federal, State and City governments did not have a clear vision, and in absence of any formal direction communities started mobilising themselves and putting pressure on local officials. Thus initially the response was 'bottom-up'. There was a collective disbelief in our group concerning the lack of preparedness and leadership amongst these local officials, despite the apparent availability of the NYC emergency handbook. That disbelief fueled sentiments of general group distrust of the government, which led to accusations that internal relationships and political affiliations between various levels of government were to blame for a complete communications and operations failure on Staten Island during and after the disaster.

Communities were in need of increased government assistance - and felt that they had been given promises - but were unable to access it (I3,I8). On the NYS level, residents felt that the Buyout Program did not include as many communities as they had hoped would be helped, leading to disillusion. From a long-term planning perspective, it seemed counterintuitive that one community would be bought out and returned to nature, while the adjacent community would be redeveloped. Our NYS interviewee pointed out, however, that despite the majority of applying communities being part of the same floodplain, this did not translate into a similar risk profile or strategy: "This is not an apples-to-apples comparison" (I4).

On the NYC level, interviewees indicated that people felt disrespected and inhumanely treated by the Build-it-Back Program, which in their eyes was overly bureaucratic and disorganised (I3). We found near unanimous negative feedback from our Staten Island interviewees and focus group concerning this program, reinforcing the existing distrust there of governments and their programs. Many community-based initiatives had therefore sprung up in response to Sandy. This was attributed to strong social cohesion within the community, but also partially because of the apparent lack of immediate government support needed 'on the ground' (I3, I8). However, it was accepted that local initiatives could never replace large-scale government programs necessary for long-term recovery.

The need for stronger local capacity was acknowledged by all interviewees. Strong regional planning relies heavily on strong local capacity (I1). Both NYC and NYS officials confirmed the need for more active public engagement during non-disaster times: these conversations 
should not be occurring immediately following disasters. Instead a plan of action needs to be in place and communicated well before any event (I4, I5). Investments in social infrastructure should take precedence over investments in physical infrastructure (I6). The NYS officials highlighted an existing effort - the Community Reconstruction Program - to identify local resilience projects, using community-based expertise (I4). An example cited was the Staten Island Alliance ${ }^{17}$ born in the aftermath of Sandy and becoming a central hub in the Ocean Breeze community (I13).

However, our interviewees indicated that this debate is not straightforward. They considered that the value of public engagement and the possibility of incentivising people to make wiser decisions came down, in essence, to two considerations: the extent to which people are capable of placing collective interests - such as, here, towards wetland conservation and its risk-reducing implications - above individual homeowner interests, and the level of expectations regarding government assistance in post-disaster situations. The seemingly inherent skepticism of Staten Islanders of any type of government intervention alienates both parties and strains communication efforts. One of the academic interviewees reflected that "It is just a process that in general Staten Islanders have so little familiarity and comfort with. Even under the best circumstances it is going to be difficult because they don't interact with government bureaucracy. They need somebody to help them, you need an inter-communicator" (I11). Faulty information was said to have been distributed to many residents in the immediate aftermath of the storm (I3, I8, I13). "Mistakes were still being made, because people don't see the next step" (I8). That led to confusion amongst residents. It highlighted the need for short-term considerations, while planning for the long-term (I11).

Major disasters were seen to expose governance vulnerabilities further feeding the community's inherent dislike of government intervention. To overcome this distrust, strengthening of permanent relationships with local civic organisations in non-disaster times is what needs to happen to increase participation in future government programming (I4,I5), particularly for measures as impactful as MR. Transparency in communication, even if that means conveying confrontational messages, is essential. People should know and understand their risks (I12). This is also the basis for NYC's planned efforts moving forward: engaging communities about risk and developing ways to mitigate that risk (I7). Alongside that level of transparency, government programming should provide residents with options for managing those risks. One of those should be a year-round buyout program (I12).

However, we infer from these findings that transparency and communication may well be necessary but perhaps is not sufficient: local leadership appears also a fundamental requirement. It cannot be a coincidence that successful buyout proposals came from communities with strong existing community associations or community leaders. The Oakwood Beach Buyout Program has received public praise for being community-driven with high buy-in and a short implementation timeframe. Many conditions had to align for that program to be successful (I2). This included a number of qualified contributors, including community leaders with real estate experience who had the knowledge and time to see the

17 http://statenislandalliance.org/ Accessed 21.12.16. 
process through and advise residents. Key contacts in upstate NY and Tennessee were also contacted for their knowledge of buyout programs. The Oakwood Beach ' 92 Committee, formed after major flooding in 1992, had been advocating flood protection for more than 20 years $^{18}$. Finally, Governor Cuomo - a crucial player promoting buyout (Rush,2015; Koslov,2016) - had a familiarity with the workings of the U.S. Department of Housing and Urban Development (HUD), the funding agency (I2). Anticipating this familiarity, the '92 Committee was able rapidly to present the Governor's Office with a HUD-conforming buyout proposal embodying limited associated political risk for local officials. A similar community cohesion and structure in place in Ocean Breeze appears there also to have boosted the potential feasibility and success of MR.

\section{Assessment and Conclusions: A dismal prognosis?}

In illustrating that managed retreat can be a feasible adaptation strategy in flood threatened coastal areas we believe our Staten Island findings are virtually unique (see the global analysis by Hino et al, 2017). With leadership, success has been achieved here at a large scale and, paradoxically, despite general support for the necessary government sponsored intervention being at a very low level.

However, we judge there are very significant political impediments as well as financial constraints to such programs being successful without a prior disaster as part of a repetitive sequence of hazardous events. Even then the likely requirements for successful implementation are numerous and demanding (Table 3) - and the MR we found at Staten Island was described as a "miracle" by one focus group community member (FG4) - but such requirements have been seemingly ignored by numerous MR advocates such as the OECD (2010), UNEP (2010), UNU-IHDP (2015) and the World Bank (2016).

Table 3. Likely requirements for successful voluntary managed retreat after a disaster strikes

\begin{tabular}{|c|c|c|}
\hline Likely requirements & $\begin{array}{l}\text { Present on Staten } \\
\text { Island? }\end{array}$ & Comment \\
\hline 1. A history of flooding & Yes & $\begin{array}{l}\text { Necessary but almost certainly } \\
\text { not sufficient }\end{array}$ \\
\hline $\begin{array}{l}\text { 2. A belief that the flood situation will get no } \\
\text { better, and might get worse in the foreseeable } \\
\text { future (i.e. a forward look that is unattractive) }\end{array}$ & Yes & Essential \\
\hline $\begin{array}{l}\text { 3. A belief that alternatives are less attractive or } \\
\text { not on offer in the foreseeable future }\end{array}$ & $\begin{array}{l}\text { Yes (i.e. the prospects } \\
\text { for the sea wall) }\end{array}$ & Essential \\
\hline $\begin{array}{l}\text { 4. Support from government/state/those who will } \\
\text { pay (MR is usually very expensive) }\end{array}$ & $\begin{array}{l}\text { Generally, yes, with } \\
\text { some significant } \\
\text { dissent (NYC) }\end{array}$ & Essential \\
\hline $\begin{array}{l}\text { 5. Trust in government and its agencies (to carry } \\
\text { MR through over a period, not for just a single } \\
\text { short period). }\end{array}$ & $\begin{array}{l}\text { Just about, thanks to } \\
\text { much community } \\
\text { action and leadership }\end{array}$ & Likely to be essential \\
\hline
\end{tabular}

${ }^{18}$ http://www.lincolninst.edu/sites/default/files/pubfiles/buy-in-for-buyouts-07161l.pdf 
6. Community consent/acquiescence in some form or other (i.e. MR seen as (a) sensible and (b) not anti-social)

7. Compensation is adequate: The value of houses plus a premium (say 10\%) for removal costs, etc

8. There is somewhere reasonably close to move to (i.e. not 100 s miles away) where house prices are similar and is (equally) attractive

9. That, for the individual householder, being left as a "hold-out" is unattractive.

Yes

Perhaps not essential if householders are willing to

"go it alone"

Probably essential

Yes, for the most part

Probably important but

Not known; not part of the offers

ifficult to judge; this depends on the individual householder

\begin{tabular}{|c|c|c|c|}
\hline & as a "hold-out" is unattractive. & & $\begin{array}{l}\text { householders are willing to } \\
\text { "go it alone" }\end{array}$ \\
\hline & $\begin{array}{l}\text { That the area will not be cleared and then } \\
\text { redeveloped (for developer profit). }\end{array}$ & Yes & $\begin{array}{l}\text { Probably important but this } \\
\text { depends on the individual } \\
\text { householder }\end{array}$ \\
\hline 11. & $\begin{array}{l}\text { The arrangements are transparent and } \\
\text { unambiguous for all to see and understand. }\end{array}$ & $\begin{array}{c}\text { Mostly, thanks to } \\
\text { community action and } \\
\text { leadership }\end{array}$ & $\begin{array}{l}\text { Probably essential to avoid a } \\
\text { suspicion of "private deals" }\end{array}$ \\
\hline 12. & $\begin{array}{l}\text { A local champion or champions to promote } \\
\text { community rather than individual MR. }\end{array}$ & Yes & $\begin{array}{c}\text { Almost certainly essential if a } \\
\text { major MR program is to } \\
\text { happen }\end{array}$ \\
\hline
\end{tabular}

Our findings suggest that the prospects for successful MR before a disaster strikes are likely to hinge on the same requirements, but for them to be even more demanding. The evidence we obtained suggests that implementation is then still very likely to be unsuccessful. The sparsity of relevant examples found by Hino et al (2017) show that such pre-disaster proposals for retreat, although apparently logical, are not acceptable to those at risk and that MR in these circumstances simply does not occur.

Our findings therefore show that pre-disaster and long-term plans for vulnerable areas are not easy to implement (at least in areas with the same socio-political character as Staten Island). We appreciate that MR needs to be located alongside and in comparison with other risk reducing measures, a dimension that Hino et al. (2017) chose to ignore. Measures such as spatial planning and development control to prevent unwise decisions and potential damage buildup appear all but impossible to implement where knowledge of the adverse impacts of recent disaster events is missing, where a policy vacuum therefore exists, or where there is the type of "light touch" spatial planning regime as on Staten Island - which the communities there knowingly or unknowingly strongly still support.

Even on Staten Island, in the shadow of Sandy, many communities have begun redevelopment, perpetuating vulnerability, not least because MR is too expensive in the short term to be universal, and - worryingly - maybe Sandy was not extreme enough or such damaging events not repeated often enough to create a sufficient "last straw" tipping point effect. 
We acknowledge that we have only researched one case study, but we judge that the same patterns are likely elsewhere, even where anti-interventionism is not so common. Implementation of MR was not easily achieved in New York and is not likely to be straightforward wherever it is voluntarily undertaken: the consensus about what triggers action toward MR shows that the "prisoner of experience" (Kates, 1962) is alive and well. It took the 1953 storm in the Netherlands and the UK to trigger those countries' defence against the sea (e.g. Waverly,1954), and it has taken Sandy-severe type 'superstorms' on many coastlines worldwide to lead to conclusions that such locations as Staten Island South Shore are too risky to develop and need to be abandoned (Hino et al,. 2017). But without first there being a disaster, MR will not happen, despite the risk probably being apparent and the relevant locations being relatively undefended. Communities at risk often have unrealistic ideas about climate change and the timescales at work, assuming damaging events, if experienced, will not recur (at least in their lifetimes). They opt to stay put.

However, such disasters do change the available information (Johnson et al., 2005; Penning-Rowsell et al., 2006). As Kates (1962) showed and Parker (1995) confirmed, individuals pre-disaster often have little information or insights as to hurricanes and other disasters events and their flood hazard potential. They build or buy where they see multiple benefits and little or no risk or need for state intervention or insurance: only 20 percent of those suffering damage from Sandy had purchased flood insurance before the storm (Botzen et al, 2015). Post-disaster they appreciate the risks all too well, and the benefits of being bought out by state agencies at favourable prices if that process becomes a new social norm. The paradox is real, but in neither situation are individuals in any sense 'irrational' as some might conclude; the information on which they act has fundamentally changed and the social contract they have with the state changes in step.

In the broader picture, it is most unlikely that all vulnerable coastal communities worldwide can be defended against likely future sea level rise (Hauer, et al, 2016; Nicholls et al, 2011; IPCC, 2013). Managed retreat will need to be commonplace, probably within a portfolio of measures to reduce risk and save lives. We judge from our research that what should happen is a mediated program of community based enquiry to work with householders and planners to reduce vulnerability at a local collective level. If community created, supported and led it should circumvent the likely anti-government sentiment. This in turn could lead to planning procedures to remove and to relocate with consensus and to find funds from disaster emergency and insurance avoidance monies to help communities develop a long term phased adaptation strategy which is constantly updated.

That is the optimistic scenario. However, based also on the research reported here, we must be realistic and assume that such pre-disaster planning and anticipatory MR for this risk reduction will rarely if ever happen. Funding for voluntary MR ahead of a disaster will often not be forthcoming; governments (as in the UK) may well refuse to resource plans to correct mistakes made in the past that were not their responsibility but resulted from local community-based decisions. Much can be done in terms of strategic planning for hazard-prone areas, but we need thereby also to plan for the worst. We may have to await the inevitable disasters, and then be ready to act: a worrying conclusion and a dismal prognosis. 


\section{References}

Albrechts, L. (2004). Strategic (spatial) planning reexamined. Environment and Planning B: Planning and Design, 31, 743-758. https://doi.org/10.1068/b3065

Alexander, K. S., Ryan, A., \& Measham, T. G. (2012). Managed retreat of coastal communities: understanding responses to projected sea level rise. Journal of Environmental Planning and Management, 55, 409-433. https://doi.org/10.1080/09640568.2011.604193

Amnesty International. (2014). Nigeria: Destitute victims of forced eviction must be adequately compensated. Dakar, Senegal: Amnesty International. Retrieved from https://www.amnesty.org/en/latest/news/2014/08/nigeria-destitute-victims-forced-eviction-mu st-be-adequately-compensated/

Barron, A. M. (2014). Opening day for the Verrazano Bridge: Festivities, fond memories -and then the floodgates open. Staten Island Advance. New York: Silvie. Retrieved from: www.silive.com. Published online: November 16 2014. Last Updated: November 162014. Accessed online: July 192015.

Barron, S., Canete, G., Carmichael, J., Flanders, D., Pond, E., Sheppard, S., \& Tatebe, K. (2012). A climate change adaptation planning process for low-lying, communities vulnerable to sea level rise. Sustainability, 4, 2176-2208. https://doi.org/10.3390/su4092176

Baumgartner, F. R., \& Jones, B. D. (1993). Agendas and instability in American politics. Chicago: University of Chicago Press.

Baussan D., \& Peterson M. (2015). Lessons from the Storm: Climate Displacement Three Years After Hurricane Sandy. Washington, DC: Centre for American Progress. Available from https://www.americanprogress.org/issues/green/report/2015/10/28/124339/lessons-from-the-s torm/. Accessed 27/09/16.

Benimoff, A. I. (2010). A GIS Study of urbanization in hurricane slosh zones on Staten Island NY. Geological Society of America Abstracts with Programs, 42(1), 146.

Benimoff, A. I., Fritz, W. J., \& Kress, M. E. (2015). Superstorm Sandy and Staten Island: Learning from the Past, Preparing for the Future. In: Bennington, J. B. \& Farmer, E. C. (Eds.) Learning from the Impact of Superstorm Sandy (pp. 21-40). Amsterdam: Elsevier. https://doi.org/10.1016/B978-0-12-801520-9.00003-1

Binder, S. B., Baker, C. K., \& Barile, J. P. (2015). Rebuild or relocate? Resilience and post-disaster decision-making after Hurricane Sandy. American Journal of Community Psychology, 56, 180-196. https://doi.org/10.1007/s10464-015-9727-x

Birkland, T. A. (1997). After disaster: Agenda setting, public policy and focusing events. Washington, DC: Georgetown University Press.

Boon, H., Millar, J., Lake, D., Cottrell, A., \& King, D. (2012). Recovery from disaster: resilience, adaptability and perceptions of climate change. Townsville, Australia: National Climate Change Adaptation Research Facility, James Cook University. 
Botzen, W. J. W., Kunreuther, H., \& Michel-Kerjan, E. (2015). Divergence between individual perceptions and objective indicators of tail risks: Evidence from floodplain residents in New York City. Judgment and Decision Making, 10, 365-6.

Breetzke, T., Parak, O., Celliers, L., Mather, A., \& Colenbrander, D. R. (Eds.) (2008). Living with coastal erosion in KwaZulu-Natal: a short-term, best practice guide. Pietermaritzburg: KwaZulu-Natal Department of Agriculture and Environmental Affairs.

Bukvic, A., Smith, A., \& Zhang, A. (2015). Evaluating drivers of coastal location in Hurricane Sandy affected communities. International Journal of Disaster Risk Reduction, 13, 215-228. https://doi.org/10.1016/j.ijdrr.2015.06.008

Carey, M. A., \& Asbury J. (2012) Focus Group Research. Walnut Creek, CA: Left Coast Press.

CCC (Climate Change Committee). (2013). Chapter 5: Regulating services - coastal habitats. London: CCC. Accessed at https://www.theccc.org.uk/wp-content/uploads/2013/07/ASC-2013-Chap5_singles_2.pdf

CIWEM. (2006). Taking Managed Realignment Forward as a Policy Option for Coastal Management in England and Wales: A CIWEM Briefing report. London: Chartered Institute for Water and Environmental Management. Accessed at http://www.ciwem.org//wp-content/uploads/2016/02/BR_ManagedRealignment.pdf

Daniel, H. (2001). Replenishment versus retreat: The cost of maintaining Delaware's beaches. Ocean and Coastal Management, 44, 87-104.

https://doi.org/10.1016/S0964-5691(00)00080-6

De Vries, D. H., \& Fraser, J. C. (2012). Citizenship rights and voluntary decision making in post-disaster US floodplain buyout mitigation programs. International Journal of Mass Emergencies and Disasters, 30, 1-33.

DEFRA and EA. (2002). Managed Realignment Review - Project Report FD2008. London: Department for Environment, Food \& Rural Affairs (DEFRA) \& Environment Agency (EA).

Esteves, L. S. (2014). Managed Realignment: A viable Long-term coastal management strategy. Dordrecht, the Netherlands: Springerbriefs in Environmental Science, Springer Science+Business Media. https://doi.org/10.1007/978-94-017-9029-1_2

Flood, S., \& Schechtman, J. (2014). The rise of resilience: Evolution of a new concept in coastal planning in Ireland and the US. Ocean and Coastal Management, 102, 19-31. https://doi.org/10.1016/j.ocecoaman.2014.08.015

Freudenberg, R., Calvin, E., Tolkoff, L., \& Brawley D. (2016). Buy-In for Buyouts. The Case for Managed Retreat from Flood Zones. Cambridge, MA: Lincoln Institute of Land Policy. Available from https://www.lincolninst.edu/publications/policy-focus-reports/buy-buyouts. Accessed 27/09/16.

Gornitz, V., Couch, S., \& Hartig, E. K. (2001). Impacts of Sea Level Rise in the New York 
City Metropolitan Area. Global and Planetary Changes, 32, 61-88.

https://doi.org/10.1016/S0921-8181(01)00150-3

Hart, G. (2011). Vulnerability and adaptation to sea-level rise in Auckland, New Zealand. Wellington, NZ: The New Zealand Climate Change Research Institute. Retrieved from http://www.victoria.ac.nz/sgees/research-centres/documents/vulnerability-and-adaptation-to-s ea-level-rise-in-auckland-new-zealand.pdf.

Hartnett, T. (2011). Consensus-Oriented Decision Making. Gabriola Island, BC, Canada: New Society Publishers.

Hino, M., Field, C. B., \& Marsh, K. J. (2017). Managed retreat as a response to natural hazard risk. Nature Climate Change, 7, 364-370. https://doi.org/10.1038/nclimate3252

IPCC. (2007). Climate change 2007: Synthesis report, fourth assessment report. Cambridge, UK: IPCC and Cambridge University Press.

IPCC. (2013). Climate change 2013: the physical science basis. Contribution of Working Group I to the Fifth Assessment Report of the Intergovernmental Panel on Climate Change. T. F. Stocker, T. F., Qin, D., Plattner, G. K., Tignor, M., Allen, S. K., Boschung, J. ..... Midgley, P. M. (Eds.). Cambridge, UK: Cambridge University Press.

Johnson, C. L., Tunstall, S. M., \& Penning-Rowsell, E. C. (2005). Floods as Catalysts for Policy Change: Historical Lessons from England and Wales. International Journal of Water Resources Development, 21, 561-575. https://doi.org/10.1080/07900620500258133

Kates, R. (1962). Hazard and choice perception in flood plain management. Chicago: University of Chicago, Department of Geography, Research Paper 78.

Knafo, S., \& Shapiro, L. (2012, December 6). Staten Island's Hurricane Sandy Damage Sheds Light On Complicated Political Battle. The Huffington Post. Retrieved from: www.huffingtonpost.com. Issue 27. Published: December 6 2012. Last updated: December 12 2012. Accessed online: July 182015.

Koslov, R. (2016). The case for retreat. Public Culture 28, 359-387.

https://doi.org/10.1215/08992363-3427487

Kousky, C. (2014). Managing shoreline retreat: A U.S. perspective. Climatic Change, 124, 9-20. https://doi.org/10.1007/s10584-014-1106-3

Kramer, D. C., \& Flanagan, R. M. (2012). Staten Island: Conservative bastion in a liberal city. New York: UPA.

Linham, M. M., \& Nicholls, R.J. (2010). Technologies for Climate Change Adaptation Coastal Erosion and Flooding. Roskilde, Denmark: UNEP Ris $\emptyset$ Centre on Energy, Climate and Sustainable Development.

Http://www.unep.org/pdf/TNAhandbook_CoastalErosionFlooding.pdf

Mather, A., \& Stretch, D. D. (2012). A Perspective on Sea Level Rise and Coastal Storm Surge from Southern and Eastern Africa: A Case Study Near Durban, South Africa. Water, 4, 
237-259. https://doi.org/10.3390/w4010237

McGranahan, G., Balk, D., \& Anderson, B., (2007). The rising tide: assessing the risks of climate change and human settlements in low elevation coastal zones. Environment \& Urbanization 19, 17-37. https://doi.org/10.1177/0956247807076960

Morgan, D. L. (1997). Focus Groups as Qualitative Research (2nd Edition). Thousand Oaks, CA: Sage Publications. https://doi.org/10.4135/9781412984287

National Oceanic and Atmospheric Administration (NOAA). (2014). Coastal Zone Management Act Section 309 Program Guidance 2016 to 2020 Enhancement Cycle. Washington, DC: NOAA.

https://coast.noaa.gov/czm/enhancement/media/Sect-309_Guidance_June2014.pdf

National Wildlife Federation (NWF) (1998). Conrad, D. R., McNitt, B., \& Stout, M. Higher Ground: A Report on Voluntary Property Buyouts in the Nation's Floodplains, A Common Ground Solution Serving People at Risk, Taxpayers and the Environment. Washington, DC: NWF.

New Jersey Department of Environmental Protection (NJ DEP (1)). (2015). Green Acres Program Areas. New Jersey: The State of New Jersey. Retrieved from: www.nj.gov. Last Updated: July 21, 2015. Accessed online: July 262015.

New Jersey Department of Environmental Protection (NJ DEP (2)). (2015). Christie Administration announces first Superstorm Sandy Blue Acres buyout in Manville. Retrieved from: www.nj.gov. New Jersey: The State of New Jersey. Published: April 21, 2015. Accessed online: July 262015.

New Jersey Department of Environmental Protection (NJ DEP (3)). (2015). The Superstorm Sandy Blue Acres Buyout Program. New Jersey: The State of New Jersey. Published: July 27, 2015.

New York City (NYC). (2015). NYC Build it Back Rebuild Program. New York: The City of New York. Retrieved from: www.nyc.gov. Accessed online: July 192015

New York City Panel on Climate Change (NPCC). (2010). Climate Change Adaptation in New York City: Building a Risk Management Response. Annals of the New York Academy of Sciences, 1196, 1-3. https://doi.org/10.1111/j.1749-6632.2009.05415.x

New York City Special Initiative for Rebuilding and Resiliency (NYC SIRR). (2013). A stronger, more resilient New York. New York: NYC SIRR.

New York City, Office of Comptroller Scott Stringer. (2015). Audit Report on the Administration of the New York City Build it Back Single Family Program by the Mayor's Office of Housing Recovery Operations. New York: New York City, Office of Comptroller Scott Stringer. Published: March 31, 2015. Retrieved from: http://comptroller.nyc.gov/ Accessed online: July 19, 2015.

New York Government (2014). State announces expanded enhanced buyout area to include 
the Graham Beach community. New York Rising. Available from:

http://stormrecovery.ny.gov/sites/default/files/uploads/graham_beach_release.pdf. Accessed 27/09/16.

New York State (NYS 2100 Commission) (2013) Recommendations to Improve the Strength and Resilience of the Empire State's Infrastructure. New York: NYS 2100. Retrieved from: http://www.governor.ny.gov/assets/ Albany, NY. Accessed online: August 162015.

New York State Governor's Office for Storm Recovery (NYS GOSR (1)). (2014). Managed Retreat: Strategies for Resiliency. New York: The 13th Annual Land Use \& Sustainable Development Conference.

New York State Governor's Office for Storm Recovery (NYS GOSR (2)). (2014, April 5). State announces expanded enhanced buyout area to include Graham Beach community. Retrieved from: http://stormrecovery.ny.gov/. New York, NY, USA. Accessed online: August 52015.

Nicholls, R. J., Marinova, N., Lowe, J. A., Brown, S., Vellinga, P., de Gusmão, D. ... Tol, R. J. (2010). Sea-level rise and its possible impacts given a 'beyond 4C world' in the twenty-first century. Philosophical Transactions of the Royal Society A, 369, 161-181.

https://doi.org/10.1098/rsta.2010.0291

Nkwunonwo, U. C., Whitworth, M., \& Baily, B. (2016). A review and critical analysis of the efforts towards urban flood risk management in the Lagos region of Nigeria. Natural Hazards and Earth System Sciences, 16, 349-369. https://doi.org/10.5194/nhess-16-349-2016

O'Riordan, T., Gomes, C. \& Schmidt, L. (2014). The Difficulties of Designing Future Coastlines in the Face of Climate Change. Landscape Research, 39, 613-30.

https://doi.org/10.1080/01426397.2014.975108

OECD. (2006). Metrics for assessing the economic benefits of climate change policies - Sea level rise. Paris: OECD. Retrieved from: Https://www.oecd.org/env/cc/37320819.pdf

Palinkas, L. A., Horwitz, S. M., Green, C. A., Wisdom, J. P., Duan, N., \& Hoagwood, K. (2014). Purposeful Sampling for Qualitative Data Collection and Analysis in Mixed Method Implementation Research. Adm. Policy. Ment. Health, 42, 533-44.

https://doi.org/10.1007/s10488-013-0528-y

Parker, D. J. (1995). Floodplain development policy in England and Wales. Applied Geography, 15, 341-363. https://doi.org/10.1016/0143-6228(95)00016-W

Penning-Rowsell, E. C., Johnson, C. and Tunstall, S. M. (2006). 'Signals' from pre-crisis discourse: Lessons from UK flooding for global environmental policy change? Global Environmental Change, 16, 323-339. https://doi.org/10.1016/j.gloenvcha.2006.01.006

Regional Plan Association (RPA). (2015). Roundtable March 2015: Where to Reinforce, Where to Retreat? New York: RPA.

Roca, E., \& Villares, M. (2012). Public perceptions of managed realignment strategies: The 
case study of the Ebro Delta in the Mediterranean basin. Ocean and Coastal Management, 60, 38-47. https://doi.org/10.1016/j.ocecoaman.2012.01.002

Rousseau, J-J. (1762). The Social Contract and Discourses by Jean-Jacques Rousseau, translated with an Introduction by G.D. H. Cole. London: J.M. Dent and Sons, published 1923.

Rush, E. (2015). Leaving the Sea: Staten Islanders Experiment with Managed Retreat. Urban Omnibus. New York: The Architectural league of New York. http://urbanomnibus.net/2015/02/leaving-the-seastaten-islanders-experiment-with-managed-r etreat/.

Ryan, A., Gorddard, R., Abel, N., Leitch, A., Alexander, K., Wise, R., ... Wise, R. (2012). Perceptions of Sea-Level Rise and Managed Retreat: An Exploratory Survey. Canberra: CSIRO: Climate Adaptation National Research Flagship.

Siders, A. (2013). Managed Coastal Retreat: A Handbook of Tools, Case Studies, and Lessons Learned. New York: Columbia Center for Climate Change Law \& Columbia Law School.

State of New York. (2015). New York State Did Not Always Administer Its Rising Home Enhanced Buyout Program in Accordance with Federal and State Regulations. New York: Governor's Office of Storm Recovery. Available from https://www.hudoig.gov/sites/default/files/documents/2015-NY-1010.pdf

Tobin, G. A. (1995). The Levee Love Affair: A Stormy Relationship. Journal of the American Water Resources Association 31, 359-367.

https://doi.org/10.1111/j.1752-1688.1995.tb04025.x

Tol, R. S. J., Klein, R. J. T., \& Nicholls, R. J. (2008). Towards Successful Adaptation to Sea-Level Rise along Europe's Coasts. Journal of Coastal Research, 24, 432-442. https://doi.org/10.2112/07A-0016.1

Trochim, W. M. (2006). The Research Methods Knowledge Base, 2nd Edition. Cincinnati, $\mathrm{OH}$ : Atomic Dog Publishing. Retrieved from: http://www.socialresearchmethods.net/kb/. Last Updated: October 20, 2006. Accessed Online: July 20, 2015.

U.S.E.P.A. (2009). Synthesis of Adaptation Options for Coastal Areas. Washington, DC: U.S. Environmental Protection Agency, Climate Ready Estuaries Program. EPA 430-F-08-024. Accessed at https://www.epa.gov/sites/production/files/2014-04/documents/cre_synthesis_1-09.pdf UNEP (2016) Managed realignment and coastal set-backs. Nairobi, Kenya: UNEP. http://web.unep.org/coastal-eba/content/managed-realignment-and-coastal-set-backs.

United States of America (U.S.) Congress (2013). Allocations, Common Applications, Waivers, and Alternative Requirements for Grantees Receiving Community Development Block Grant (CDBG) Disaster Recovery Funds in Response to Hurricane Sandy. 78 Federal Register Notice 14, 345: March 5, 2013. 
Waverley, J. V. (1954). Report of the Departmental Committee on Coastal Flooding. London: H.M.S.O.

White, G. F. (1960). Strategic Aspects of Urban Flood Plain Occupance. Journal of the Hydraulics Division, Proceedings of the American Society of Civil Engineers 86, 89-102.

Wong, P. P., Losada, I. J., Gattuso, J. P., Hinkel, J., Khattabi, A., McInnes, K. L., .. Sallenger, A. (2014). Coastal systems and low-lying areas. In: Climate Change 2014: Impacts, Adaptation, and Vulnerability. Part A: Global and Sectoral Aspects. Contribution of Working Group II to the Fifth Assessment Report of the Intergovernmental Panel on Climate Change [Field, C.B. V.R. Barros, D.J. Dokken, K.J. Mach, M.D. Mastrandrea, T.E. Bilir, M. Chatterjee, K.L. Ebi, Y.O. Estrada, R.C. Genova, B. Girma, E.S. Kissel, A.N. Levy, S. MacCracken, P.R. Mastrandrea, and L.L. White (eds.)]. Cambridge, UK: Cambridge University Press. Accessed at http://www.ipcc.ch/pdf/assessment-report/ar5/wg2/WGIIAR5-Chap5_FINAL.pdf

World Bank (WACA) (2016). Managing Coastal Risks in West Africa. Washington, DC: The World

Bank. http://documents.worldbank.org/curated/en/624481467995659649/pdf/101185-REVISED-PU BLIC-WACA-KS3-Managing-Coastal-Risks-April-2016.pdf

World Bank. (2010). Resettlement Action Plan (March), 1-21. Accessed at: http://documents.worldbank.org/curated/en/558391468097760996/Resettlement-action-plan-f or-TSM-group-B-and-D-junctions

\section{Copyright Disclaimer}

Copyright for this article is retained by the author(s), with first publication rights granted to the journal.

This is an open-access article distributed under the terms and conditions of the Creative Commons Attribution license (http://creativecommons.org/licenses/by/3.0/). 